\title{
Evaluation of Brinjal (Solanum melongena L.) Germplasm Lines for Yield Related Parameters and Collar Rot Resistance
}

\author{
M. Nikitha ${ }^{1 *}$, B. Neeraja Prabhakar ${ }^{2}$, M. Padma $^{3}$, Bharati N. Bhat ${ }^{4}$ and N. Sivaraj ${ }^{5}$ \\ ${ }^{1}$ Department of Vegetable Science, ${ }^{3}$ Department of Horticulture, College of Horticulture, \\ Sri Konda Laxman Telangana State Horticultural University, Rajendranagar, \\ Hyderabad-500030, Telangana, India \\ ${ }^{2}$ Department of Horticulture, ${ }^{4}$ Department of Plant Pathology, PJTSAU, Rajendranagar, \\ Hyderabad-500030, Telangana, India \\ ${ }^{5}$ Economic Botany, NBPGR Regional Station, Rajendranagar, Hyderabad-500030, \\ Telangana, India \\ *Corresponding author
}

\section{A B S T R A C T}

\section{Keywords}

Brinjal, Genotypes, Mean performance, Screening,

Sclerotium rolfsii, Resistance

\section{Article Info}

Accepted:

26 August 2020

Available Online:

10 September 2020
Thirty-three brinjal genotypes received from NBPGR, Hyderabad were screened for collar rot disease and their mean performances were also assessed for yield related parameters at SKLTSHU, Hyderabad during Kharif, 2019. These genotypes were laid in Randomized Block Design with two replications to study the diversity and were laid in Completely Randomized Design with three replications in polybags to identify the resistant germplasm lines. The fungus was isolated from diseased brinjal plants of farmer's field, purified and maintained on PDA for further experimentation. Mass culture of the pathogen was prepared on sorghum grains and inoculated in polybags before transplanting. The analysis of variance showed highly significant differences among the genotypes for all the traits studied. The genotype IC-136182 was superior for yield characters i.e., yield per plant (2.39 kg plant $\left.{ }^{-1}\right)$ and marketable yield per plant (1.16 kg plant $\left.{ }^{-1}\right)$ and IC-136366 recorded highest plant height $(104 \mathrm{~cm})$. Out of all genotypes studied, only four genotypes viz., IC111074, IC-089905, Bhagyamathi and Arka Kusumakar exhibited resistant response while, the remaining shown susceptible to highly susceptible disease reaction for collar rot disease.The resistant genotypes identified through screening and mean performance can be used further for development of collar rot resistant high yielding genotypes.

\section{Introduction}

Brinjal (Solanum melongena $\mathrm{L}$.; $2 \mathrm{n}=24$ ) also known as eggplant or aubergine or guinea squash, is an important crop of sub-tropics and tropics. It belongs to Solanaceae family included under the genus of Solanum which is one of the largest genera covering more than 1550 species.

According to De Candolle (1883), eggplant was known in India in ancient times and probably a native of India (Vavilov, 1928). Brinjal is a versatile crop which is adapted to 
different agro-climatic regions and grown throughout the year and throughout the country. It is commercially grown as an annual but it is perennial crop. Major producers are West Bengal, Odisha, Andhra Pradesh, Gujarat and Bihar. Brinjal fruits are a fairly good source of calcium, phosphorus, iron and vitamins, particularly vit-B group. Along with tomato and onion it ranks as the second most consumed vegetable in India after potato with $8.3 \%$ production share.

The fruit of brinjal is very popular among peoples of all social strata and hence, it is rightly called as vegetable of masses (Choudhary and Kalda, 1968). In India, brinjal occupies an area of 735 thousand ha and production is around 12987 thousand tonnes. (NHB Database, 2018-19).

Improvement in yield is achieved by selecting genotypes with desirable character combinations existing within the nature or by hybridization. Morphological characterization is the first step in the description and classification of germplasm collections (Smith and Smith, 1989). As brinjal is susceptible to several diseases such as damping off, wilt, collar rot etc. the development of resistant varieties is a major challenge of which Fusarium oxysporum f. sp. melongena, Rhizoctonia solani, Sclerotium rolfsii are the most common.

Use of synthetic chemicals probably can kill the beneficial soil microflora. Sclerotium rolfsii Sacc. is a soil borne pathogen responsible for root and stem rot on a wide range of crops and it is difficult to control by physical and cultural practices due to its wide host range of over 500 plant species (Aycock, 1966; Punja, 1985) and persistent sclerotia (Punja, 1985; Lakpale, 2007).

Cultivation of resistant genotypes is the best method of managing the disease. Besides resistance to pathogen, these lines can be used for hybridization programme to evolve cultivars possessing desirable traits. Considering the above facts, the investigation was conducted to evaluate the brinjal genotypes for desirable characters and collar rot (Sclerotium rolfsii) resistance.

\section{Materials and Methods}

\section{Procedure regarding performance of genotypes}

The present investigation was carried out at PG Research block, College of Horticulture, Rajendranagar, SKLTSHU during Kharif, 2019. Thirty-three genotypes were laid out in Randomized Block Design with two replications and followed a spacing of $60 \mathrm{~cm} \times$ $60 \mathrm{~cm}$. The experimental material of genotypes were procured from NBPGR, Hyderabad.

All recommended package of practices and need based plant protection measures were followed to ensure a good crop. Observations (Plant height, fruit length, fruit diameter, number of fruits per plant, fruit weight, yield per plant and marketable yield per plant) regarding performance of genotypes were recorded on five randomly selected plants in each replication.

\section{Procedure regarding screening of genotypes}

\section{Isolation and Maintenance of the Pathogen}

Naturally infected brinjal plants showing typical symptoms of collar rot disease were collected from the field of Chenvelli village, Rangareddy district, Telangana, washed thoroughly with distilled water, blot dried and cut with sharp sterilized blade into small bits (5mm). These bits were then surface sterilized with 0.1 per cent aqueous solution of mercuric 
chloride $\left(\mathrm{HgCl}_{2}\right)$ for two minutes, washed by giving three successive changes with sterile distilled water in glass Petri plates to remove traces of mercuric chloride and blot dried.

These sterilized bits were then inoculated aseptically on autoclaved and cooled PDA medium in sterilized glass Petri plates under aseptic conditions of Laminar-air-flow cabinet and then incubated in BOD incubator at $28+2^{\circ} \mathrm{C}$ temperature. Within $2-3$ days of incubation, whitish mycelial mat was developed.

Within next 10-12 days, numerous brown black sclerotia were developed in the petri plate. Employing hyphal tip and single spore (sclerotia) isolation technique, the test pathogen was transferred aseptically on the PDA slant in test tubes.

Through frequent sub-culturing, the test pathogen was purified and the pure culture was maintained in a refrigerator for further studies.

\section{Mass multiplication of Sclerotium rolfsii}

The pathogen was individually mass multiplied on sorghum grains (Gupta and Kolte, 1982). Sorghum grains were presoaked in water overnight. Later, the excess water is removed and the soaked grains was transferred into 1000ml flasks @ $400 \mathrm{~g}$ and autoclaved at $15 \mathrm{psi}\left(121.6^{\circ} \mathrm{C}\right)$ for $20 \mathrm{~min}$. The flasks were allowed to cool at room temperature and inoculated with $5 \mathrm{~mm}$ discs from actively growing 5 day old cultures of $S$. rolfsii. Seven discs per flask were added and the flasks were later incubated for 10 days at $26+2^{\circ} \mathrm{C}$.

\section{Soil sterilization}

Potting mixture of soil, vermicompost and FYM in the ratio of 2:1:1 was sterilized by using Nano silver hydrogen peroxide @ 4ml $\mathrm{lt}^{-1}$ and later soil was inoculated with fungus.

\section{Inoculation of Sclerotium rolfsiifungus}

Soil inoculation technique was followed for inoculation of the pathogen. To each polybag, $40 \mathrm{~g}$ of inoculum multiplied on sorghum grains was added and mixed with the soil to a depth of $5 \mathrm{~cm}$ and covered with the soil.

The polybags were inoculated 45 days after sowing (Shokes et al., 1996). A total of three replications, three polybags per replication, and two plants per polybag were maintained. The seedling mortality per cent was calculated at 30 days after inoculation.

\section{Screening of brinjal germplasm against collar rot pathogen}

Brinjal lines were transplanted in polybags of $12 "$ x 5" size and 350 guage thickness and filled with sterilized soil. These polybags were laid in Completely Randomized Design with three replications.

Three polybags were used for each replication and each polybag was transplanted with two brinjal seedlings. In each polybag, two plants were transplanted. The polybags were immediately watered for two consecutive days after inoculation.

\section{Assessment of disease incidence and severity}

The collar rot disease in brinjal was assessed based on wilt symptoms, appearance of mycelium and sclerotial bodies at the root zone. The severity was measured for every 15 days starting from the day of inoculation.

Wilt symptoms and the number of wilted plants for each genotype were recorded and graded 1-5 scale according to Shokes et al., (1996)

Where in,

$1=$ Healthy plants 
$2=$ Lesions on stem only

$3=\mathrm{Up}$ to $25 \%$ of the plants symptomatic (wilted, dead or decaying)

$4=26-50 \%$ of the plants symptomatic (wilted, dead or decaying) and

$5=>50 \%$ of the plants symptomatic (wilted, dead or decaying).

\section{Results and Discussion}

The results of mean performances of 33 genotypes for different characters revealed that the genotype IC-136182 was superior for yield characters i.e., yield per plant $(2.39 \mathrm{~kg}$ plant $\left.^{-1}\right)$ and marketable yield per plant (1.16 kg plant ${ }^{-1}$ ).

While the genotype IC-136366 recorded highest plant height $(104 \mathrm{~cm})$. Highest fruit diameter was reported in the genotype IC136297.

The genotype IC-89910 produced maximum number of fruits per plant (41.00) whereas, the genotype IC-136222 was superior for fruit weight $(98.50 \mathrm{~g})$. The check variety, Arka Kusumakar recorded highest fruit length $(11.51 \mathrm{~cm})$.

The per cent of collar rot disease incidence in the brinjal genotypes was recorded and presented in the table 1. Disease symptoms were observed on these brinjal seedlings as water-soaked spots which turned to rot soon.

These spots resulted in wilting and death of plants during their maturation. The fungus mycelia extended around the stems and on the soil surface. Sclerotia were also observed on these mycelia.

The data revealed that the incidence of collar rot disease ranged from $16.66 \%$ to $83.33 \%$.
The minimum (16.66 \%) collar rot incidence was recorded in the genotype IC-111074 (0.67 kgplant $\left.{ }^{-1}\right)$ which is followed by the genotype IC-089905 with yield performance of $1.09 \mathrm{~kg}$ plant $^{-1}$ shown a disease incidence of 22.22 per cent which was equal to the checks Bhagyamathi (22.22 \%), Arka Kusumakar $(22.22 \%)$ and lesser than Pusa Purple Long (61.11\%).

The maximum disease incidence was observed for the genotype IC-136251 (83.33 $\%)$ followed by the genotypes IC-136249 (77.77\%) and IC-136268 (77.77\%).

Significant differences in disease incidence were noticed among different genotypes. Out of all the genotypes studied, 22 genotypes i.e., IC-136349, IC-136309, IC-144525, IC112341, IC-136251, IC-136366, IC-136006, IC-136258, IC-136461, IC-136249, IC136308, IC-136222, IC-144515, IC-136297, IC-136296, IC-136182, IC-136268, IC112315, IC-136546, IC-136196, IC-89910 and Pusa Purple Long were shown more than $50 \%$ susceptibility and scoring was given accordingly.

As brinjal is susceptible to several diseases such as damping off, wilt, root rot, collar rot etc. the development of resistant varieties is a major challenge of which Sclerotium rolfsii is most common.

Use of fungicides can prevent the growth of fungus to some extent but the use of synthetic chemicals would probably kill the beneficial soil microflora and hinder the growth of the plant to some extent. Therefore, resistant varieties of crop plants will result to escape such diseases (Fig. 1-4). 
Table.1 Mean performance of yield associated characters and per cent incidence of collar rot disease in 33 genotypes of brinjal

\begin{tabular}{|c|c|c|c|c|c|c|c|c|c|c|c|}
\hline $\begin{array}{l}\dot{Z} \\
\dot{n}\end{array}$ & $\sum_{0}^{0}$ & 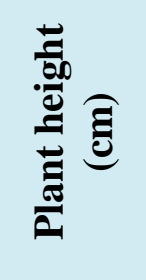 & 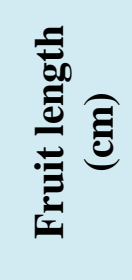 & 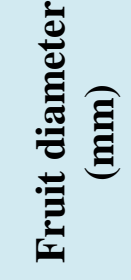 & 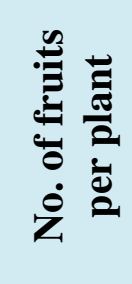 & 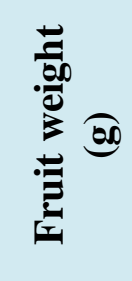 & 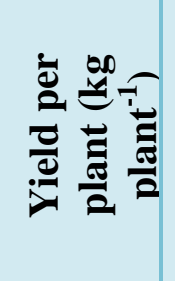 & 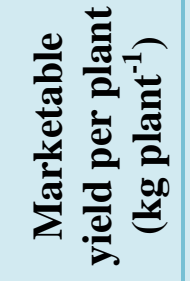 & 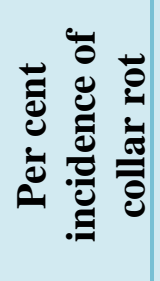 & 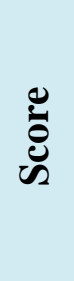 & 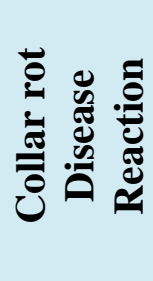 \\
\hline 1. & IC-136349 & 103.00 & 9.15 & 38.23 & 14.50 & 56.30 & 0.85 & 0.40 & 55.55 & 5 & HS \\
\hline 2. & IC-136303 & 92.50 & 8.80 & 49.59 & 7.50 & 81.60 & 0.89 & 0.25 & 44.44 & 4 & $S$ \\
\hline 3. & IC-136061 & 77.50 & 8.65 & 44.33 & 7.50 & 71.65 & 0.52 & 0.21 & 44.44 & 4 & S \\
\hline 4. & IC-136309 & 83.50 & 7.50 & 46.45 & 10.00 & 82.50 & 0.84 & 0.34 & 55.55 & 5 & HS \\
\hline 5. & IC-089905 & 69.00 & 8.35 & 51.98 & 12.50 & 87.50 & 1.09 & 0.53 & 22.22 & 3 & $\mathrm{R}$ \\
\hline 6. & IC-111074 & 74.50 & 9.40 & 44.07 & 9.00 & 75.00 & 0.67 & 0.26 & 16.66 & 3 & $\mathrm{R}$ \\
\hline 7. & IC-144525 & 66.00 & 6.65 & 39.36 & 17.00 & 51.15 & 0.99 & 0.46 & 55.55 & 5 & HS \\
\hline 8. & IC-112341 & 84.00 & 6.10 & 56.08 & 10.00 & 87.50 & 0.87 & 0.40 & 61.11 & 5 & HS \\
\hline 9. & IC-136251 & 97.00 & 7.55 & 45.50 & 7.50 & 80.00 & 0.59 & 0.19 & 83.33 & 5 & HS \\
\hline 10. & IC-212426 & 86.00 & 6.35 & 56.33 & 12.00 & 87.50 & 1.07 & 0.54 & 44.44 & 4 & S \\
\hline 11. & IC-136366 & 104.00 & 8.20 & 46.60 & 10.00 & 82.50 & 0.81 & 0.40 & 55.55 & 5 & HS \\
\hline 12. & IC-136006 & 64.00 & 7.20 & 56.54 & 5.50 & 80.50 & 0.45 & 0.17 & 55.55 & 5 & HS \\
\hline 13. & IC-136258 & 41.00 & 6.30 & 51.38 & 8.50 & 75.50 & 0.65 & 0.27 & 55.55 & 5 & HS \\
\hline 14. & IC-136461 & 44.00 & 8.55 & 43.84 & 12.50 & 62.50 & 0.79 & 0.38 & 55.55 & 5 & HS \\
\hline 15. & IC-136249 & 85.00 & 9.90 & 52.77 & 15.50 & 78.50 & 1.22 & 0.51 & 77.77 & 5 & HS \\
\hline 16. & IC-136308 & 87.50 & 9.10 & 51.25 & 19.00 & 72.50 & 1.34 & 0.60 & 72.22 & 5 & HS \\
\hline 17. & IC-136300 & 89.00 & 7.35 & 52.42 & 16.50 & 73.00 & 1.20 & 0.55 & 50.00 & 4 & S \\
\hline 18. & IC-136222 & 66.00 & 6.50 & 54.18 & 16.50 & 98.50 & 1.63 & 0.75 & 72.22 & 5 & HS \\
\hline
\end{tabular}


Table.1 (Contd...)

\begin{tabular}{|c|c|c|c|c|c|c|c|c|c|c|c|}
\hline $\begin{array}{l}\dot{z} \\
\dot{n}\end{array}$ & 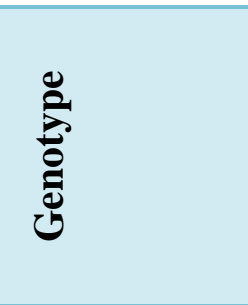 & 氖 & 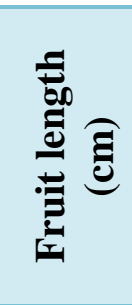 & 离 & 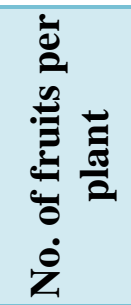 & 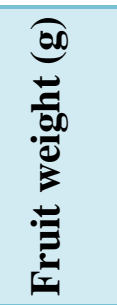 & 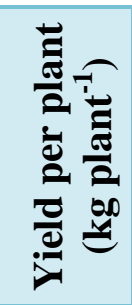 & 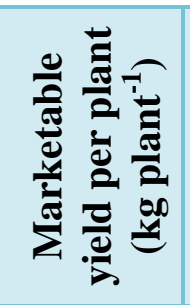 & 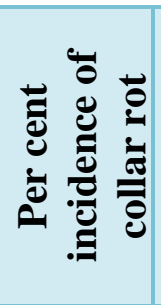 & : & 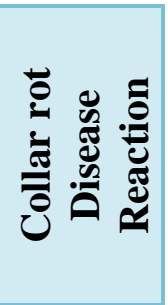 \\
\hline 19. & IC-144515 & 83.50 & 10.50 & 38.59 & 18.50 & 51.35 & 1.06 & 0.49 & 55.55 & 5 & HS \\
\hline 20. & IC-136297 & 70.50 & 6.50 & 60.67 & 22.00 & 90.00 & 1.97 & 0.99 & 66.66 & 5 & HS \\
\hline 21. & IC-136296 & 82.50 & 10.65 & 40.41 & 23.50 & 61.00 & 1.41 & 0.63 & 66.66 & 5 & HS \\
\hline 22. & IC-136182 & 72.50 & 7.35 & 53.60 & 31.00 & 77.50 & 2.39 & 1.16 & 66.66 & 5 & HS \\
\hline 23. & IC-136268 & 98.00 & 11.45 & 44.74 & 16.50 & 80.00 & 1.31 & 0.60 & 77.77 & 5 & HS \\
\hline 24. & IC-136307 & 75.00 & 9.30 & 41.91 & 11.50 & 67.50 & 0.79 & 0.42 & 44.44 & 4 & $\mathrm{~S}$ \\
\hline 25. & IC-112315 & 56.50 & 8.35 & 39.41 & 10.50 & 53.00 & 0.55 & 0.27 & 55.55 & 5 & HS \\
\hline 26. & IC-203589 & 68.50 & 8.20 & 53.42 & 17.00 & 79.00 & 1.34 & 0.67 & 44.44 & 4 & S \\
\hline 27. & IC-136546 & 52.50 & 5.95 & 52.27 & 14.00 & 62.50 & 0.86 & 0.37 & 55.55 & 5 & HS \\
\hline 28. & IC-136196 & 49.00 & 7.70 & 44.21 & 13.00 & 62.50 & 0.81 & 0.34 & 72.22 & 5 & HS \\
\hline 29. & IC-136177 & 69.00 & 7.45 & 45.93 & 11.00 & 82.50 & 0.91 & 0.43 & 50.00 & 4 & S \\
\hline 30. & IC-89910 & 68.50 & 8.50 & 41.27 & 41.00 & 56.00 & 2.37 & 0.48 & 72.22 & 5 & HS \\
\hline 31. & Bhagyamathi & 96.00 & 7.30 & 53.68 & 10.00 & 67.50 & 0.67 & 1.10 & 22.22 & 3 & $\mathrm{R}$ \\
\hline 32. & $\begin{array}{l}\text { Pusa Purple } \\
\text { Long }\end{array}$ & 69.80 & 7.40 & 48.11 & 13.00 & 68.50 & 0.89 & 0.27 & 61.11 & 5 & HS \\
\hline 33. & $\begin{array}{l}\text { Arka } \\
\text { Kusumakar }\end{array}$ & 69.32 & 11.51 & 26.90 & 22.00 & 57.50 & 1.28 & 0.45 & 22.22 & 3 & $\mathrm{R}$ \\
\hline
\end{tabular}


Fig.1 Colony morphology and sclerotia production of Sclerotium rolfsii on PDA
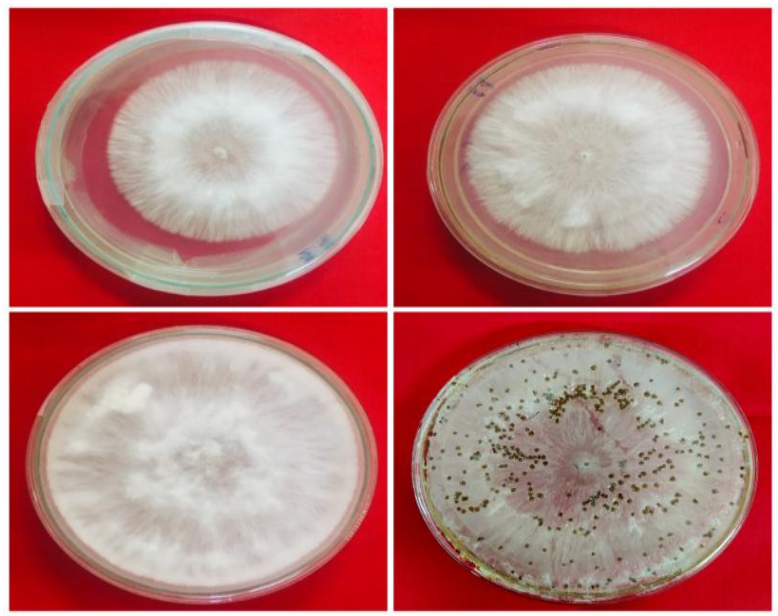

Fig.2 Mycelial growth and sclerotial bodies observed at the soil line after artificial inoculation of fungus
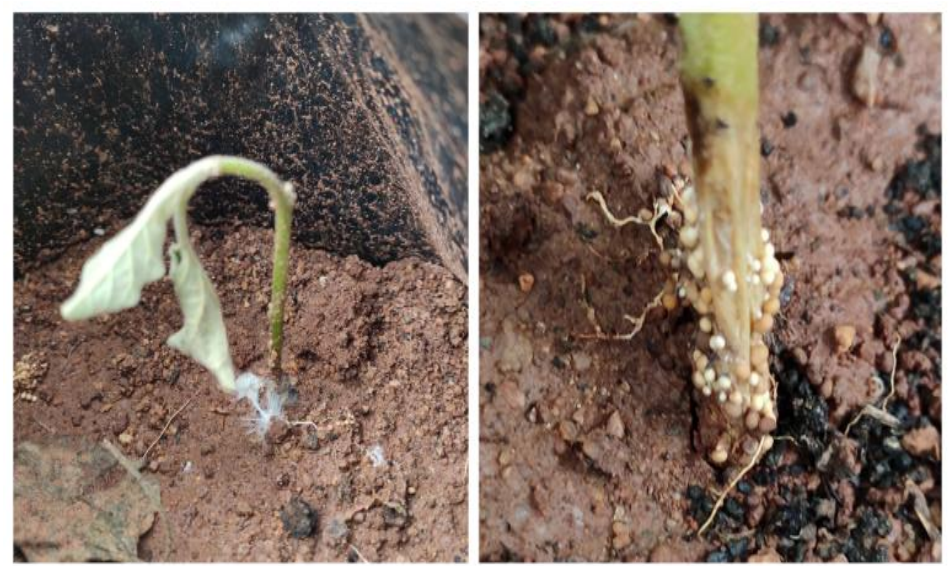

Fig.3 Resistant genotypes: (i) IC-089905 (ii) IC-111074

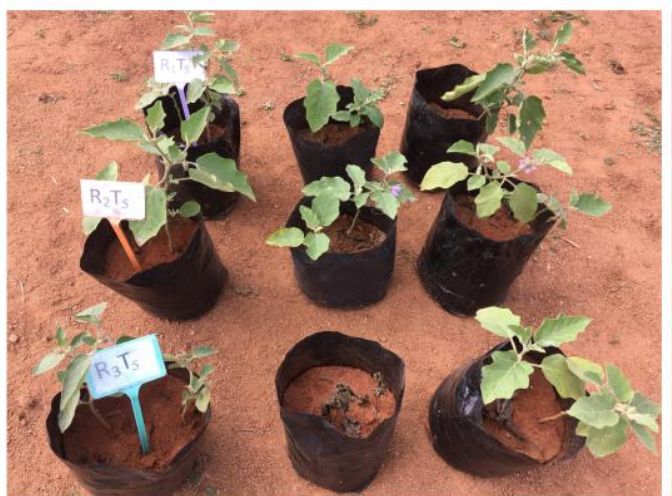

(A)

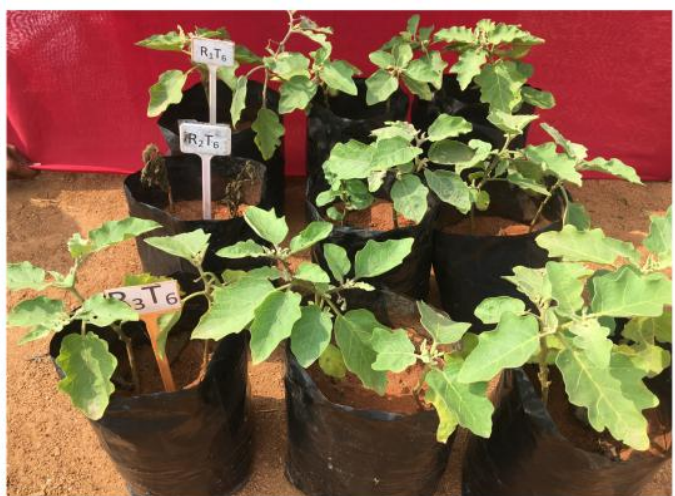

(B) 
Fig.4 Susceptible genotypes: (i) IC-136251 (ii) IC-136461

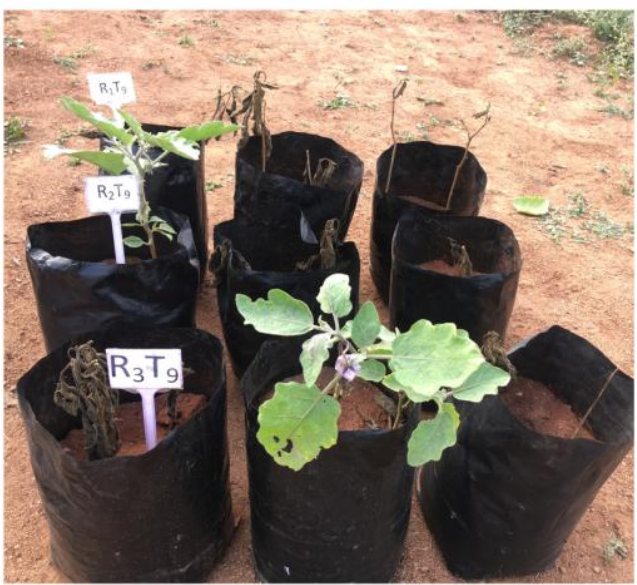

(A)

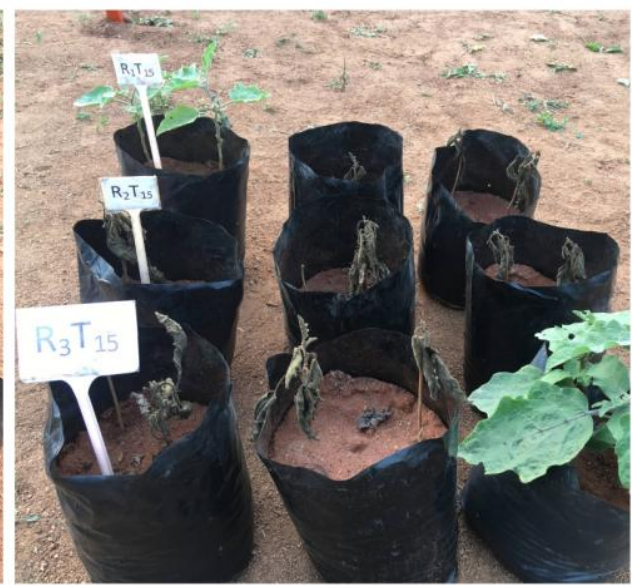

(B)
Cultivation of resistant genotypes is the best method of managing such disease. Regarding the brinjal genotypes evaluation of resistance, most of the genotypes were susceptible to the selected fungus and the resistant reaction was observed only in few genotypes. The results were similar to the results reported by Sugha et al., (1990), Faruque (2008), Richa et al., (2018).

Genotypes found resistant were namely, IC111074 and IC-089905. Besides resistance to soil borne pathogen, these lines can be further used for hybridization programme to evolve cultivars possessing desirable traits.

\section{References}

Aycock, R. 1966. Stem rot and other diseases caused by Sclerotium rolfsii. North Carolina Agricultural Experiment Station Technical Bulletin. 174, 202.

Choudhary, B. and Kalda, T. S. 1968. Brinjal: A vegetable of the masses. Indian Horticulture. 12(3): 21-22.

De Candolle, A. P. 1883. Origin des plantes. 150.

Gupta, S. C. and Kolte, S. J. 1982. A comparative study of two isolates of Macrophomina phaseolina from leaf and root rot groundnut. Indian Phytopathol. 35: 222 - 225.

Lakpale, N., Khare, N. and Thrimurty, V. S. 2007. Suppression of Sclerotium rolfsii Sacc. : an integrated approach. Soils and Crops. 17: 241-245.

National Horticulture Board. 2018-19. National Horticulture Database. Ministry of Agriculture, Government of India, Guargon, India.

Punja, Z. K. 1985. The biology, ecology, and control of Sclerotium rolfsii. Annu. Rev. Phytopathol. 23: 97-127.

Shokes, F. M., Rozalski, K., Gorbet, D. W., Brenneman, T. B. and Berger, D. A. 1996. Techniques for inoculation of peanut with Sclerotium rolfsii in the greenhouse and field. Peanut Science. 23: 124-128.

Smith, J. S. C. and Smith, O. S. 1989. The description and assessment of distances between inbred lines of maize: The utility of morphological, biochemical, and genetic descriptors and a scheme for the testing of distinctiveness between inbred lines. Maydica. 34:151161.

Vavilov, N. I. 1928. Proceedings of 5th International Congress of Genetics. New York. Pp. 342-369. 


\section{How to cite this article:}

Nikitha, M., B. Neeraja Prabhakar, M. Padma, Bharati N. Bhat and Sivaraj, N. 2020. Evaluation of Brinjal (Solanum melongena L.) Germplasm Lines for Yield Related Parameters and Collar Rot Resistance. Int.J.Curr.Microbiol.App.Sci. 9(09): 3216-3224.

doi: https://doi.org/10.20546/ijcmas.2020.909.398 